Tanja S. Cvetković ${ }^{1}$

University of Niš

Faculty of Philosophy

\title{
POSTMODERN SATIRE AS MEANS OF REWRITING MYTHS IN THE STUDHORSE MAN
}

\begin{abstract}
Satire is one of the most prominent features of Canadian literature and as such has been mapped in the writing of Canadian postmodern author Robert Kroetsch in this paper. The paper will focus on Robert Kroetsch's award winning novel The Studhorse Man (1969) and will examine the way postmodern satire shatters the dominant heroic myths placing Kroetsch closer to other novelists of the "New Western Myth" in North America as Leslie Fiedler describes in The Return of the Vanishing American. Kroetsch's subversion of the dominant system is briefly related to Bakhtin's carnival theory as well. The paper explores satire within the postmodern theory of writing by looking at the story of the novel as the parody of the quest myth in the West and the main hero Hazard Lepage as a comic travesty of the Western hero in quest. Kroetsch de-mythologizes the West by using satire as a powerful means to recreate old stories into new ones. In conclusion, the author of the paper proves that in this novel Kroetsch creates a new prairie reality and experience through this particular story which becomes his authentic way of relating to Canadian reality.

Keywords: postmodern satire, New Western Myth, New World myth, quest myth, carnival theory, demythologization
\end{abstract}

\section{Finding "a neat way out"}

The Studhorse Man (1969) is the second novel of Out West Triptych (comprising also The Words of My Roaring (1966) and Gone Indian (1973)) written by the Canadian author Robert Kroetsch. The novel won Governor General Award in 1969, one of the most prestigious literary awards in Canada. In the novel the author uses a couple of postmodern techniques to spin the story which takes place in the Canadian West in Alberta at the end of the Second World War.

In the vein of his poetics, Kroetsch uses the technique of retelling old stories and mythical fragments in a new original way, which points to his urge to introduce change and novelty in his work. Satire and parody that pervade the text is yet another technique at the basis of which is the subversion of the old dominant orders and systems and the inversion of order. As a result of retelling and shattering old stories, mythical fragments, conventional narrative

1 tanjac@junis.ni.ac.rs

2 This paper was presented at the $21^{\text {st }}$ Congress of International Comparative Literature Association at the University of Vienna, Vienna, Austria, in July 2016. 
patterns and ideologies, Kroetsch's stories generate multiple meanings, revealing his inclination to deconstruction and demythologization.

With this novel Kroetsch seems to be searching for an authentic Canadian myth and a voice to shape that myth. In his essays published in The Lovely Treachery of Words Kroetsch argues that the Canadian writer must uninvent the world to win back an independent authentic voice. In order to reach what is authentic and Canadian he must destroy the American and English language and experience. He explains: "In recent Canadian fiction the major writers resolve the paradox - the painful tension between appearance and authenticity - by the radical process of demythologizing the systems that threaten to define them. Or, more comprehensively, they uninvent the world" (Kroetsch 1989: 58). Consequently, the rejection of literary conventions, old value systems and ideologies, implies a means of giving a new "voice" to Canadian fiction.

By subverting old traditional systems and meanings, one gives way for new meanings to emerge. In Kroetsch's poetics, a narrative, or a mythical fragment, put in a new context, generates a new version of itself and a new possibility, which adds to the generative function of myth (Kroetsch 1982: 128). As the task of the writer is to "uninvent the world", under the layers of old inherited meanings and conventions, Kroetsch discovers new meanings and employs them into new contexts producing new stories.

Kroetsch's use of satire and parody to subvert dominant systems can be associated to the carnival theory of Mikhail Bakhtin. According to the Russian philosopher and literary critic Bakhtin, carnival represents a temporary liberation from the prevailing established order marking the suspension of hierarchical norms and prohibitions. It marks the time of the destruction of the old order, renewal and the incoming new order. Bakhtin describes the carnivalesque culture:

As opposed to the official feast, one might say that carnival celebrated temporary liberation from the prevailing truth and from the established order; it marked the suspension of all hierarchical rank, privileges, norms, and prohibitions. Carnival was the true feast of time, the feast of becoming, changes, and renewal. It was hostile to all that was immortalized and completed (Bakhtin 1965: 10).

In Bakhtin's carnivalesque world, hierarchies and divisions disappear, the opposites unite and merge into one another, which leads to transformation, change and renewal. Carnival is the liberation of the suppressed energy and the essence of such a culture consists of: festivity, feast, jest, but also of destruction because carnival entails the change of the order. The central event of the novel, the wedding of Tiberius and Catherine, is of carnivalesque nature and marks the point when transformations begin in the novel. The event subverts the dominant narration and plot in the novel.

The story of The Studhorse Man is the story about Hazard Lepage and his quest for a perfect mare for his stallion Poseidon. The story is told by the unreliable first person narrator, Demeter Proudfoot, a self-proclaimed lunatic, who spends most of his time in the psychiatric asylum, naked in the bathtub, trying to compose the biography of Hazard Lepage, the owner of the last stal- 
lion in the line of Lepage blue roans. Hazard, as a very greedy man, whose family motto is "nothing in moderation" (Kroetsch 1977: 120) wanders across Alberta prairies in search of a mare. Rising against history, the closure of the system, Hazard's trickster's nature is an antithesis to the way he is imagined by Demeter, and is based on similarity, the notion of causality, fact, order, which compose some of the basic characteristics of the $19^{\text {th }}$-century realism in literature.

After having participated in the Great War in France, Hazard returns to Alberta and starts his twenty four year quest. He encounters many obstacles. After having an argument about payment, he boards the train in a wrong direction which takes him far away from his house Burkhardt and Coulee Hill where his fiancée Martha Proudfoot lives. Martha has five excellent mares but she does not want to yield them to Hazard. Hazard arrives in Edmonton, spends a night with P. Cockburn, the assistant curator, and wearing the uniform of the Royal Canadian Mounted Police arrives at the Home for Incurables which is led by Sister Raphael. He finds a mare while roaming the south of Alberta. At the moment of his triumph, he is arrested for using the mare without license and is sentenced to nine days in jail or three day work on the farm. While working on the farm, he ends up in bed with Mrs. Lank, the owner of the farm. Then he meets Eugene Utter and attends the wedding of Martha's relatives. He is seduced at Marie Eshpeter's ranch who tries to steal Poseidon's seed in order to sell it. Hazard manages to escape to Mrs. Laporte's house where he is almost killed by fire. Finally, he is killed by Poseidon in his own house, Eugene marries Martha, and Poseidon's urine is used for making a birth control pill. Hazard ends his quest unsuccessfully.

The text of the novel parodies realism as a literary movement, historical linear time-scheme which modernists thought necessary and the use of mythical fragments (myths from classical mythology (the myth of Orpheus, Narcissus, Odysseus, Demeter, Poseidon, as well as Canadian national myth) creating a way for a new form of myth - New World myth, according to Marie Vautier, professor of comparative Canadian literature and Quebecois literature at the University of Victoria. Parodying mythical fragments in the text confirms postmodern idea that myth is a narrative device employed not as a structuring and controlling principle but as an incoherent, non hierarchical device used to gain access to older experience. Kroetsch also reenacts the national myth by using the pun on the meaning of the words mare (a female horse) and Latin mare - sea in the Canadian motto "A mari usque ad mare" ("From sea to sea") in Lepage's search for a mare from coast to coast. The ironic treatment of the main hero and traditional myths brings Kroetsch closer to another new form of myth, the New Western myth as described by Leslie Fiedler in The Return of the Vanishing American (Fiedler 1968: 159-168).

The Studhorse Man can be read both in the light of New Western and New World myth. The weakening of the modernist function of myth pave the way for the presence of the New World myth, which, according to Vautier is "rather a paradigm of myth" (Vautier 1998: 45), which reveals how myth is used to suit a particular need in a particular time and place. Vautier further 
defines New World myth as myth which "encourages a renewed interest in reclaiming the past, and yet flaunts its re-creation, through story, of the past in the here and now" (Vautier 1998: 45). Its emphasis is on the narrator as the creative teller of untold tales which underscores the flexibility of New World myth. It also features a deliberate putting aside of classical myths, which in Kroetsch's texts shows as an ironic treatment and inversion of mythical fragments. Another feature of New World myth is its metafictional aspect putting more weight on the creative making. This feature could be traced in Kroetsch's novel as well.

What Kroetsch chronicles in his Out West Triptych is the fall of the West according to Dick Harrison (Harrison 1977: 206), which is ironically related to the cowboy mythology of the Wild West which stands for strength, violence, virility. Instead of being the agent of virility, the main hero Hazard Lepage is a parody of the hero from the old West. Hazard is not handsome nor does he know how to fight. He can't control his destiny; he is seduced by women and is killed by his horse at the end. Hazard's fall coincides with the fall of the West with the horse as the appropriate image of the vanishing prairie values. Carrying all the associations of freedom, power and pride, the horse appears to represent the free spirit of an earlier "unrestrained" West. At the end of the novel the loss of the West is explained in terms of the loss of fertility and the mechanization which replaces the free spirit of the horse.

Like the myth of the Wild West, horse, as the central symbol in the novel, is satirized too. Poseidon is Hazard's pristine sexual energy, the embodiment of life and death. It is Hazard's authentic self, his animal identity, his distant ancestor and totem, coyote, whom he tries to preserve within himself. Trusting his totem, his coyote, Hazard did not want to give a name to his studhorse believing that the horse had a name simply by belonging to him. Even when he first appears in the novel, Hazard crawls up from the hole full of bones: cow, horse, buffalo bones which he wants to sell. Like horse, bones represent secret layers of prairie history marking the agricultural rural period. The novel itself describes a significant period in prairie history, the transition from agricultural rural to urban industrial way of life in the Canadian West.

The ironic treatment of mythical symbols and stories is part of demythologizing process. In the novel, demythologizing leads to the clash between historical and mythical consciousness and shreds the world back to its original chaos. The clash between historical and mythic consciousness is closely explained by the figures of Demeter and Hazard in the novel. In Kroetsch's work chaos partly results from author's resort to madness, fantasies, hallucinations and absurdity which again aligns him with the writers of the New Western in America. For example, Ken Kesey's One Flew Over the Cuckoo's Nest is set in a mental asylum and Kroetsch's Demeter writes from a mental hospital too. According to Fiedler, the madness in the New Western "signifies the ultimate West, the final escape from the White reason and intellect which has tyrannized over America from the beginning (Fiedler 1968: 185). Demeter is the historical consciousness who attempts to impose reason and significance to 
Hazard's chaotic experience, which became mythic when interpreted as the decline of the West.

Demeter and Hazard are Kroetsch's pair of opposed characters. Hazard is the symbol of action, chaos, change, while Demeter embodies order and passivity. They represent Kroetsch's stand on narration based on parody. The novel is about the very process of writing, the relationship between the narrator and the story, which is both creative and destructive. Demeter Proudfoot is the narrator who struggles to tell the story of Hazard Lepage. Both characters survive in the novel because the author reunites them at one point. So, Demeter, the unreliable first person narrator tells somebody's story which becomes his own at the end.

Demeter's story is the parody of realism as a literary trend. He wants to construct Hazard's story as a work of art which will be grounded on the $19^{\text {th }}$ century literary conventions. He sees himself as an author who has to shape Hazard's story in time so that Hazard's biography should have the beginning, the middle and the end. His urge to cast experience and the plot in a linear form, to put human experience in causality relates clearly Demeter's attempt to mimetic theory which is inherent to realistic trend in literature. Supporting mimetic theory, Demeter sees life outside the asylum as it has been reflected in the mirror above the sink:

By a fortunate combination of light and reflection, I am able to see out of my window without leaving my bathtub. A mirror is so placed above my sink that I have been able to sit for hours, attempting to imagine what in fact did happen (allowing for the reversal of the image) exactly where I imagine it. It is then time that I must reconstruct, not space (Kroetsch 1977: 85).

Like the inverted picture of the external world in the mirror, Demeter tries to maintain order and structure Hazard's experience based on chance and irrationality. Demeter is attracted to biography as it represents a possibility to reconstruct time and its human aspect. In a paradoxical way Demeter opposes chaos and ambiguity and is forced to tell the story in a postmodern way. He sees himself as an artist - biographer whom he calls "a seeker after truth" (Kroetsch 1977: 34) claiming that "we who assemble fragments long for a whole image of he vanished past" (Kroetsch 1977: 34). As he longs for the whole time-scheme, he directs Hazard's experience towards the belief that "it is then time that [he] must reconstruct, not space" (Kroetsch 1977: 85).

As a trickster figure in the novel, Hazard negates history and order, strives for ambiguity and chaos, and embodies phallic power. While Demeter is interested in cerebral existence, Hazard believes in his phallic power which, for him, is a kind of physical rather than imaginative creativity. While Demeter stays in his bathtub naked, Hazard wanders across the prairie in search of a mare. Demeter is passive and static, has a proclivity to reflection and meditation, while Hazard is impulsive and his actions are the result of his physical needs. Hazard replaces one adventure by other both in a physical and a sexual way. Demeter's frustrated need to control Hazard's experience results from his wish to structure illogical postmodern world that Hazard represents. 
Hazard opposes Demeter's idea to be defined in time, as well as historical linear process of world making. That's why he tried to "damn the past into the oblivion he felt it richly deserved" (Kroetsch 1977: 20). Not only has he "peculiar little aversion to history" (Kroetsch 1977: 32) but he was also "terrified of history" (Kroetsch 1977: 33). His rejection of history results from his rejection of the notion of time.

Eugene Utter is the extreme example of the negation of history in the novel. He is unscrupulous and ready to benefit from Hazard's death - he marries Hazard's fiancée and employs Poseidon's capacities for artificial insemination. Hazard meets Eugene on his voyage: "It was one of the peculiarities of this Utter fellow that he inspired others to excess" (Kroetsch 1977: 87) and it was Eugene to suggest to Hazard "only some last little motion of the spirit to complete our journey" (Kroetsch 1977: 97) before he sets fire to the school, their only shelter, as they remain naked in a cold night. His urge for freedom is clearly defined when he says: "But we are free men at last; we are what that woman herself called Svobodniki!" (Kroetsch 1977: 98). The urge for freedom and the negation of any form of ownership is Eugene's apocalyptic answer to historical creations and structures cultivated by fathers and authorities as well as his renunciation of duty, commitment and responsibility.

The rejection of any kind of restraint and the acceptance of individual and collective suppressed energy is illustrated by the carnivalesque event, the wedding feast of Tiberius and Catherine Melnyk. The wedding is the culmination of laughter, dance, celebration, the exuberance of food and drink and joy. After this episode, a series of destructive events follows: Marie Eshpeter steals Poseidon's seed, the school is set to fire when Hazard almost dies and Hazard's eventual death at the end of the novel. The feast ends in sexual exuberance of Demeter and Veronica, one of the guests. It initiates the subversion of the dominant system: for Hazard it is the beginning of his sexual frustrations; for Demeter it is the point when he assumes Hazard's identity. From that point on, Demeter loses the precision of recording events and his identity merges with Hazard's up to the point when he concludes that "that morning I was D. Proudfoot, Studhorse Man" (Kroetsch 1977: 156). The carnival abolishes all hierarchies, the opposites unite and give rise to change.

A similar sort of subversion, the shattering of the dominant systems, is exemplified by the inversion of mythical fragments employed in the text: the myth of Odysseus, the myth of Orpheus, the myth of Narcissus, Demeter and Poseidon, fertility myth.

The Narcissistic motifs in the novel are closely related to the myth of Orpheus. Both Demeter's and Hazard's character could be read in this light. Demeter retreats within himself, and focuses his energy on writing Hazard's biography. He does not want to connect with the Other as he remains isolated in his bathtub. Like mythical Narcissus, he withdraws into himself, and like comic Orpheus, Demeter tries to reconstruct the world the way he sees it in the mirror. Hazard's obsession with his phallic power is opposed to Demeter's love for words. Demeter's inability to order Hazard's experience is replaced by Hazard's sexuality and his fall into silence. Language and words cannot ex- 
press man's longing for life and death. Demeter's retreat without any reference to the external world is associated to the mythical story of Narcissus; his need to tell the story brings him closer to Orpheus who tries to express his personal agony through art.

The story of Hazard is the parody of the classical Odysseus myth as well. Hazard's role in the novel is similar to Odysseus' in the Greek myth. Thus, Martha is Penelope, the Second World War is the Trojan War, Demeter who fights for Martha is Telemachus and Hazard's quest for a mare corresponds to Odysseus' wanderings and his quest for his native Ithaca. Kroetsch makes a pun of the words (English mare and Latin mare - sea; French mer - sea) when Cassandra in the novel in the form of an old woman foretells Hazard's destiny: "La mer sera votre meurtrière”. Hazard's home Burkhardt looks like Ithaca and is inhabited by Martha's suitors.

The Odysseus analogue, loosely employed in Hazard's wondering, can be traced further on. Hazard's journey by train when he dreams of Martha has a reference to the land of Lotus eaters which he can leave only if he visits Hades:

"Where in hell -" Hazard began again.

"No." The brakeman laughed encouragingly. “In Edmonton.” (Kroetsch 1977: 24)

In order to survive, Hazard must escape from Edmonton, the city of the Royal Canadian Mounted Police, from the museum of Canadian history, from the land of Laestrygonians and the Cyclopean embrace of P. Cockburn.

After the land of Laestrygonians, there appears Circe as Sister Raphael and her Home for the Incurables. When Sister Raphael invites Hazard and says "Come", her words echo through the shadows of the barn. One adventure follows another. The choice between jail and Mrs. Lank parallels the choice between Scylla and Charybdis. Marie Eshpeter becomes the nymph Calypso, and Mrs. Laporte is Nausicaä. However, these comparisons are insignificant regarding their broader meaning. The contrast between contemporary Canada and Homeric Greece underscores the contrast between life and art, history and immortality.

According to Kroetsch's dialectics, where one opposite gives birth to another, the epic and realistic conventions are undermined, mythical fragments inverted and parodied. In that vein, The Studhorse Man is the inversion of the great Odysseus myth. From the point of view of its narrative structure, it has forty two chapters, while Homer's epic poem has twenty four. Kroetsch's Odysseus, Hazard Lepage, fascinated by mares and sexual adventures, moves from one adventure to another, never arriving to his Ithaca. His search and roaming oppose Demeter's rules:"Every journey is a journey home?" (Kroetsch 1977: 155). In Kroetsch's novel, every journey does not end by finding home. Hazard is forced to get back to his mansion where he is killed by Poseidon. The search for sexual adventures and mares is the search for creativity which does not take the comic Odysseus, Hazard Lepage, home or to a place where the narration ends. Overtaking Hazard's role, Demeter does not end his search nor does he allow his hero to make a pause. At the end, accepting mimetic technique and imitating reality, mocking the Odysseus myth, Demeter 
announces the end of Hazard's search: "My journey had begun. Hazard had failed" (Kroetsch 1977: 155).

It is difficult to see where the story ends. Hazard dies, but is reborn as Demeter. Demeter's system for Hazard's story and his time-scheme are destroyed. Demeter comes to a conclusion that "art would find a neat way out" (Kroetsch 1977: 142), but The Studhorse Man does not find such a way out. Heroic contexts which Demeter uses to tell Hazard's story are demythologized. The last pages of the novel point to destruction, the inversion of mythical and historical structures which Demeter bases his biography of Hazard Lepage on. Canadian history is turned to ashes when Poseidon smashes "the walls patterned white and blue and gold with alternating lions and fleurs-de-lis" (Kroetsch 1977: 10, 170). Hazard comes back to Ithaca to die. And Penelope (Martha Proudfoot) marries her suitor Eugene Utter. Poseidon's seed is finally employed for insemination and birth control. Every logical end of the novel is inverted. If there is an end, then Kroetsch's belief that "there's no way to put it all together without ... letting the contradictions ride" (Marshall 1980: 43) remains true.

Demeter's biography of Hazard Lepage and his quest story are a bad, unreliable narrator's, reconstruction of events who cannot bridge the gap between fiction and reality. Moreover, the story represents an absurd way of fictive depiction of reality. Instead of reflecting reality, the story reflects itself, i.e. the process of creating reality. The Studhorse Man becomes metafiction: the story about writing a story. Since Demeter fails to finish Hazard's biography because he tells the story of Hazard which eventually becomes his own, Demeter's sterile creativity and repetition are the main traits of the novel. Demeter meditates and comes to a conclusion:

Men of more experience than I have lamented at the repetitious nature of the ultimate creative act itself. It is only by a mastery of the process of repetition [...] that we can learn to endure; yet we can only master the process by a lifetime of repetition. Many, I suspect, are tempted to despair. But I have sought other solutions and, I might add, with no little success. The path that would appear to lead to madness is surely the highroad to art (Kroetsch 1977: 127-128).

This is how Demeter Proudfoot describes a creative act and the problem of a contemporary man and writer who abandons traditional narrative conventions.

In the context of Kroetsch's novels and his stand on myth, myth and stories are broken down into fragments, the free combination of which, by way of parody and satire, produce new meanings other that the ones that are given and codified by different patterns. The whole text is self-reflective in a postmodern sense and is based on Kroetsch's efforts to "shape the story while the story is at the same time shattered, to incorporate myth and story in the text while they are disintegrated, to show the truth by insisting on the multiple views" (Cvetković 2010: 225-226). As he creates a new prairie reality, experience and history through a new local and particular story and myth, in this novel Kroetsch creates a new story about Canadian nation because he believes 
that "the task of the Canadian writer [is] to give names to his experience, to be the namer" and that "he works with a language, within a literature, that appears to be authentically his own, and not a borrowing” (Kroetsch 1989: 58). Kroetsch's small isolated stories, notes and fragments are his authentic way of relating to Canadian reality.

\section{References:}

Bahtin 1965: M. Bakhtin, Rabelais and His World, Cambridge, Mass.: MIT Press.

Cvetković 2010: T. Cvetković, Izmedju mita i tišine: Kanadska književnost, postmodernizam i Zapadni triptih Roberta Krouča. Beograd: Nolit.

Fidler 1968: L. Fiedler, The Return of the Vanishing American, New York: Stein and Day.

Harison 1977: D. Harrison, Unnamed Country: The Struggle for a Canadian Prairie Fiction. Edmonton: University of Alberta Press.

Krouč 1977: R. Kroetsch, The Studhorse Man. Markham: PaperJacks Ltd.

Krouč 1989: R. Kroetsch, The Lovely Treachery of Words: Essays Selected and New. Toronto: Oxford University Press.

Leker 1986: R. Lecker, Robert Kroetsch. Boston: G.K. Hall \& Co.

Maršal 1980: J. Marshall, „From The Remembrance Day Tapes”, Island 7 (1980): 43.

Njuman, Vilson 1982: S. Neuman, R. Wilson. The Labyrinths of Voice: Conversations with Robert Kroetsch. Edmonton: NeWest Press.

Votije 1998: M. Vautier, New World Myth: Postmodernism and Postcolonialism in Canadian Fiction. Montreal and Kingston: McGill-Queens University Press.

Тања С. Цветковић

\section{ПОСТМОДЕРНА САТИРА КАО СРЕДСТВО ПОНОВНОГ ЗАПИСИВАҢА МИТОВА У РОМАНУ ВЛАСНИК ПАСТУВА}

Резиме

Сатира је једна од најпрепознатљивијих црта канадске књижевности и као такву је препознајемо и код канадског писца Роберта Кроуча у овом раду.

Рад се бави награђиваним романом Роберта Кроуча The Studhorse Man (1969) (Власник йасйува) и проучава постмодерну сатиру која подрива доминантне митове и истовремено позиционира Кроуча ближе него било ког другог писца „Новом Вестерн миту” у Северној Америци, као што Лезли Фидлер описује у делу The Return of the Vanishing American (Повратак изг̄убленог̄ Американца). Кроучово подривање доминантних система објашњава се и Бахтиновом теоријом карневала.

Рад се бави сатиром у оквиру постмодерне теорије посматрајући причу романа као пародију мита о потрази на западу главног јунака Хазарда Лепажа као комичну травестију западног хероја у потрази. Кроуч демитологизира Запад преко сатире као моћног средства да старе приче претвори у нове. 
Као закључак, аутор рада доказује да у овом роману Кроуч ствара нову преријску стварност и искуство кроз појединачну причу која постаје аутентичан начин његовог односа са канадском стварношћу.

Кључне речи: постмодерна сатира, Нови Вестерн мит, Нови светски мит, мит о потрази, карневалска теорија, демитологизација

Примлен 14. децембра 2016. голине Прихваћен 2. аирила 2017. голине 